\title{
Synergistic Catalytic Properties of Bifunctional Nanoalloy Catalysts in Rechargeable Lithium-Oxygen Battery
}

Ning Kang a , Mei Shan $\mathrm{Ng}^{\text {a }}$, Shiyao Shan ${ }^{\mathrm{a}}$, Jinfang $\mathrm{Wu}^{\text {a }}$, Wei Zhao ${ }^{\mathrm{a}}$, Jun Yin ${ }^{\text {a }}$, Weiqing Fang ${ }^{\mathrm{a}}$, Jin Luo ${ }^{\mathrm{a}}$, Valeri Petkov ${ }^{\mathrm{b}}$, and Chuan-Jian Zhong ${ }^{\mathrm{a} *}$

a) Department of Chemistry, State University of New York at Binghamton, Binghamton, New York 13902, USA

b) Department of Physics, Central Michigan University, Mt. Pleasant, Michigan 48859, USA

(* To whom correspondence should be addressed: cjzhong@binghamton.edu)

Abstract. The understanding of factors influencing the performance of catalysts in the air cathode of a rechargeable lithium-oxygen battery, including overpotentials for oxygen reduction/evolution and discharge capacity, is essential for exploration of its ultimate application. This report describes new findings of an investigation of $\mathrm{PdCu}$ nanoalloys as cathode catalysts. Alloying Pd with oxophilic base metals such as $\mathrm{Cu}$ leads to reduction of the overpotentials and increase of the discharge capacity. The nanoalloy structures depend on the bimetallic composition, with an atomic ration near 50:50 featuring mixed bcc and fcc structures. The discharge potential exhibits a maximum while the charge potential display a minimum in the range of $20 \sim 50 \% \mathrm{Cu}$, closer to $25 \%$, both of which correspond to a maximum reduction of the discharge-charge overpotentials. The discharge capacity displays a gradual increase with $\mathrm{Cu} \%$. This type of catalytic synergy is believed to be associated with a combination of ensemble and ligand effects. In particular, the activation of oxygen on Pd sites and oxygen oxophilicity at the alloyed $\mathrm{Cu}$ sites in the catalyst may have played an important role in effectively activating oxygen and maneuvering surface superoxide/peroxide species. These findings have implications to the design of multifunctional cathode catalysts in rechargeable lithium-oxygen batteries.

Keywords: Lithium-oxygen batteries; bimetallic alloy catalysts; synergistic effect; discharge and charge potentials. 


\section{Introduction}

Rechargeable lithium-oxygen batteries, as one of the most promising electrochemical energy storage devices for electric vehicles, have recently attracted increasing interests due to high theoretical energy density and gravimetric energy, which are 3-10 times higher than the current lithium-ion batteries [1-2]. However, major challenges for practical applications of the rechargeable lithium-oxygen batteries included limited cyclability, relatively high voltage in the charge process, low capacity retention during cycling, as well as decomposition of solvent. To overcome these difficulties, there is a surge of research activities focusing on the air cathode materials [3-5] where the oxygen reduction reaction (ORR) during discharge and the oxygen evolution reaction (OER) during charge occur. The formation of lithium superoxide/peroxide species on the air cathode is unique in non-aqueous environment, which depends on the hydrophobicity and polarity of the electrolytes [6-8]. While many of the recent studies have focused on the electrolyte effects on the battery performance characteristics [9-12], the profound understanding of the cathode materials and catalysts is rather limited [13-18]. Previous studies of bimetallic PtAu catalysts showed that the surface of $\mathrm{Au}$ and $\mathrm{Pt}$ atoms are catalytic functional for ORR and OER kinetics, respectively [19-21], and this type of catalytic function also relies on the nanoscale structural characteristics including size, composition, and phase properties [22]. Excepting for noble metals, metal oxide such as $\mathrm{Co}_{3} \mathrm{O}_{4}$ nanofibers is also reported [23, 24]. The utilization of graphene as supporting materials could enhance catalytic activity, electronic conductivity and cyclability. The formation of carbonate ions during charging could restrain the decomposition of electrolyte.

The charge-discharge overpotentials rely on the catalyst activity, whereas the enhancement of discharge capacity depends on the mutual effect of catalyst activity and overall catalyst structure. Due to the deposition of lithium superoxide/peroxide species on the air cathode, it is very challenging to determine the most critical factors that terminate lithium-oxygen battery discharge process in terms of capacity and the overpotential. The complication also arises from clogging of pores in the air cathode, the blockage of catalytically active sites on the surface, and the loss of electrode conductivity [25]. Excepting 
for the endeavor that has been employed on the reduction of overpotentials, approaches to addressing the deposition of discharge product on air cathode are also important. The deposition of $\mathrm{Li}_{2} \mathrm{O}_{2} / \mathrm{LiO}_{2}$ product will poison the catalyst, which requires a thorough investigation of the design of the catalyst. It is essential to keep the catalytic active site constantly refreshed by the sites next to it with a balanced oxophilicity to facilitate the deposition and removal of $\mathrm{Li}_{2} \mathrm{O}_{2} / \mathrm{LiO}_{2}$ product.

In addition to the control of the nanoscale composition, the control of the phase properties is also important which is extensively demonstrated in AuPt and other binary/ternary catalysts for ORR [26-33]. In a recent study, with the utilization of benzyl amine, bimetallic nanoparticles with controlled phases of disordered fcc and orderd $\mathrm{B} 2$ type $\mathrm{PdCu}$ is proved to have a superior performance on lithium-oxygen battery. The weight ratio of crystal face (111) in the fcc and (110) in the B2-type is 49:51, the nanoparticles displays surpassing round-trip efficiency of $80 \%$. Moreover, the OER potential is as low as 2.73V and a 3.4V ORR over potential is also achieved. Theoretical studies (DFT) have shown that Pd (111) surface has low adsorption strength $(3.46 \mathrm{eV})$, compared with its co-metals $\mathrm{Cu}(-4.41 \mathrm{eV})$ in the $\mathrm{PdCu}$. Pd-skin with (111) surface in alloy is considered to be the active sites for $\mathrm{LiO}_{2}$ adsorptions [34]. In our early work we also studied the PdCu nanoparticles as bimetallic nanoalloy, it showed great catalytic potential in ethanol oxidation reaction [35]. Very recently, we found that the catalytic activity of $\mathrm{PdCu}$ relies on the composition and structure. With the utilization of high energy XRD, it has been proved that mixed phases of bcc type and fcc type have great influence on $\mathrm{CO}$ oxidation. We demonstrated that ordering of nearby $\mathrm{Pd}$ and $\mathrm{Cu}$ atoms could strongly enhance the catalytic activity of $\mathrm{PdCu}$ nanoparticles with a composition of around 50:50 [36].

We show herein new findings to demonstrate that the control of the nanoscale alloying composition and structure plays an important role in the manipulation of the catalyst performance characteristics. A key approach involves alloying $\mathrm{Pd}$ with a transition base metal such as $\mathrm{Cu}$ in different compositions, which is known tunable in terms of oxophilicity. $\mathrm{Pd}$ is unique in catalytic activity towards oxygen reduction/oxidation, though not yet demonstrated sufficiently in lithium-oxygen battery. The motivation 
of exploring $\mathrm{PdCu}$ alloys as a potential catalyst arises from the synergy effect of the nanoalloy in the overpotentials. Pd could facilitate catalytic reduction of oxygen to peroxide species, as well as the discharge capacity due to the oxygen oxophilicity when alloyed with $\mathrm{Cu}$. $\mathrm{PdCu}$ has been studied as catalysts for ORR and MOR (methanol oxidation reaction) [37], insertion of $\mathrm{Cu}$ into $\mathrm{Pd}$ lattice not only reduces the lattice constant, but also traps $\mathrm{OH}$ while keeping $\mathrm{Pd}$ site available for $\mathrm{O}_{2}$ adsorption. Computational modeling [38] has suggested that the $\mathrm{O}_{2}$ adsorption energy depends on the bimetallic composition, displaying an optimal composition $(30 \% \mathrm{Cu})$ for the adsorption of $\mathrm{O}_{2}$ in ORR. The understanding of how to balance the activation of oxygen on Pd sites and the oxophilicity or oxygen storage capacity on the alloyed $\mathrm{Cu}$ sites is crucial for the discharge-charge processes and expected to provide useful information for the design of multifunctional catalysts for rechargeable lithium-oxygen batteries. Moreover, the utilization of Pd, instead of Pt, could also reduce the cost of catalyst since Pd's cost is about $1 / 3$ of $\mathrm{Pt}$ with an abundance of three times higher than Pt. Besides alloying of Pd with $\mathrm{Cu}$ further reduces the cost, which is another key issue to motivate this study.

\section{Experimental}

\subsection{Chemical}

Palladium (II) acetylacetonate (Pd (acac) 2, 97\%), Copper (II) acetylacetonate (Cu (acac) 2, 97\%), benzyl ether $\left(\left(\mathrm{C}_{6} \mathrm{H}_{5} \mathrm{CH}_{2}\right)_{2} \mathrm{O},>98 \%\right)$, oleylamine $\left(\mathrm{CH}_{3}\left(\mathrm{CH}_{2}\right)_{7} \mathrm{CH} \mathrm{CH}\left(\mathrm{CH}_{2}\right)_{8} \mathrm{NH}_{2}, 70 \%\right)$, and oleic acid $\left(\mathrm{CH}_{3}\left(\mathrm{CH}_{2}\right)_{7} \mathrm{CH} \mathrm{CH}\left(\mathrm{CH}_{2}\right)_{7} \mathrm{COOH}, 99+\%\right)$ were purchased from Aldrich and used as received. Other chemicals such as ethanol and hexane were purchased from Fisher Scientific. Vulcan carbon XC-72 was from Cabot. Reticulated vitreous carbon (RVC, pore \# 30 PPI) was obtained from Ultramet. Pd (20\% on activated carbon (Pearlman's catalyst), unreduced, 50\% water wet paste (Escat ${ }^{\mathrm{TM}}$ 1951, BASF Kit)) were obtained from Strem Chemicals.

\subsection{Synthesis of PdCu nanoalloys and preparation of carbon supported catalysts.}

The synthesis of $\mathrm{PdCu}$ nanoparticles followed the protocol reported in our previous reports [39] with slight modifications. Briefly, palladium (II) acetylacetonate and copper (II) acetylacetonate in a 
controlled molar ratio were dissolved into benzyl ether solvent. Then oleic acid and oleylamine were added as the capping agent under $\mathrm{N}_{2}$ atmosphere. 1, 2-hexadecanediol was added as the reducing agent. With the temperature increase to $105^{\circ} \mathrm{C}$, the metal precursors were starting to decompose and the solution was becoming dark. Then, $\mathrm{N}_{2}$ purging was stopped and the mixture was heated up to $220{ }^{\circ} \mathrm{C}$ with reflux for $0.5 \mathrm{hr}$. The color of the solution appeared black and was collected until it was cool down to the room temperature. The nanoparticles were precipitated by adding ethanol through centrifuging and dispersed in hexane solvent for future use. While the feeding ratios were $25 \%, 50 \%$ and $75 \% \mathrm{Cu}$, the actual compositions for the nanoparticles prepared from different batches, as measured by ICP-AES, were very close to, but not exactly the same as the feeding compositions. In this report we used the actual compositions of the nanoparticles.

The catalysts were prepared from the as-synthesized nanoparticles. Carbon black XC-72 was used as support materials which were suspended in hexane solvent and sonicated in ice bath for 3 hrs. A controlled amount of as-synthesized nanoparticles was added into the solution followed by sonication and overnight stirring. The carbon-supported nanoparticles were obtained by evaporating the solvent under inert gas.

The carbon-supported nanoparticles were activated by thermochemical processes, details were reported previously $[39,40]$. Typically, the carbon-supported sample was annealed under $20 \% \mathrm{O}_{2}$ (in $\mathrm{N}_{2}$ ) for $1 \mathrm{hr}$ at $260^{\circ} \mathrm{C}$ and $15 \% \mathrm{H}_{2}$ (in $\mathrm{N}_{2}$ ) for $2 \mathrm{hr}$ at $400^{\circ} \mathrm{C}$ before further characterizations. Some samples were annealed under $\mathrm{N}_{2}$ instead of $\mathrm{O} 2$ under same condition followed by $\mathrm{H}_{2}$ treatment.

The commercial $\mathrm{Pd} / \mathrm{C}$ catalyst was thermally treated at $400{ }^{\circ} \mathrm{C}$ in $15 \% \mathrm{H}_{2}$ (in $\mathrm{N}_{2}$ ) for $1 \mathrm{~h}$ before further analysis. Catalysts of three different bimetallic compositions, including $\mathrm{Pd}_{21} \mathrm{Cu}_{79} / \mathrm{C}, \mathrm{Pd}_{53} \mathrm{Cu}_{47} / \mathrm{C}$, and $\mathrm{Pd}_{75} \mathrm{Cu}_{25} / \mathrm{C}$, were studied. Since $\mathrm{Pd}_{21} \mathrm{Cu}_{79} / \mathrm{C}$ showed the most promising $\mathrm{Li}-\mathrm{O}_{2}$ performance characteristic, the data for this catalyst are described in a great detail.

\subsection{Instrumentation and Measurements.}


X-ray Powder Diffraction (XRD) data was obtained using a Philips X'Pert diffractometer with $\mathrm{Cu}$ KR radiation $(\lambda=1.5406 \AA)$. The measurements were carried out in reflection geometry and the diffraction (Bragg) angles $2 \theta$ were scanned at a step of $0.025^{\circ} \cdot \mathrm{min}^{-1}$. Some data were also obtained using Scintag XDS2000 $\theta-\theta$ diffractometer (CuKa $\lambda=1.5406 \AA$ ), equipped with a Ge (Li) solid state detector. The XRD data was collected from 20 to 90 degree $2 \theta$ at a rate of $0.58^{\circ} \mathrm{min}^{-1}$ at room temperature. Synchrotron High-Energy XRD (HE-XRD) with atomic pair distribution functions (PDFs) measurements were carried out at Sector 11 of the Advanced Photon Source in ex-situ mode using x-ray (wavelength, $\lambda=0.1080 \AA$ ).

Experimental XRD data were corrected for experimental artifacts, reduced to the so-called structure factors, $S(q)$, and then Fourier transformed to atomic PDFs $G(r)$. In the present experiments XRD data was collected up to wave vectors $\mathrm{q}_{\max }$ of $25 \AA^{-1}$. Note, as derived, atomic PDFs G(r) are experimental quantities that oscillate around zero and show positive peaks at real space distances, $r$, where the local atomic density $\rho(r)$ exceeds the average one $\rho_{0}$. This behavior can be expressed by the equation $G(r)=$ $4 \pi \mathrm{r} \rho_{\mathrm{o}}\left[\rho(\mathrm{r}) / \rho_{\mathrm{o}}-1\right]$, which is the formal definition of the PDF G(r).

Catalyst samples were analyzed using inductively-coupled plasma optical emission spectroscopy (ICP-OES), which was performed using a Perkin Elmer 2000 DV ICP-OES utilizing a cross flow nebulizer with the following parameters: plasma $18.0 \mathrm{~L} \mathrm{Ar}_{(\mathrm{g})} \cdot \mathrm{min}^{-1}$; auxiliary $0.3 \mathrm{~L} \mathrm{Ar}_{(\mathrm{g})} \cdot \mathrm{min}^{-1}$; nebulizer $0.73 \mathrm{~L} \operatorname{Ar}_{(\mathrm{g})} \cdot \min ^{-1}$; power $1500 \mathrm{~W}$; peristaltic pump rate $1.40 \mathrm{~mL} \cdot \mathrm{min}^{-1}$. Reported values $<1.0 \mathrm{mg} \cdot \mathrm{L}^{-1}$ were analyzed using a Meinhardt nebulizer coupled to a cyclonic spray chamber to increase analyte sensitivity at the following parameters: $18.0 \mathrm{~L} \operatorname{Ar}_{(\mathrm{g})} \cdot \mathrm{min}^{-1}$; auxiliary $0.3 \mathrm{~L} \mathrm{Ar}_{(\mathrm{g})} \cdot \mathrm{min}^{-1}$; nebulizer $0.63 \mathrm{~L}$ $\operatorname{Ar}_{(\mathrm{g})} \cdot \mathrm{min}^{-1}$; power $1500 \mathrm{~W}$; peristaltic pump rate $1.00 \mathrm{~mL} \cdot \mathrm{min}^{-1}$. Elemental concentrations were determined by measuring one or more emission lines $(\mathrm{nm})$ to check for interferences. The nanoparticle samples were dissolved in concentrated aqua regia, and then diluted to a concentration with the range of 1 to $50 \mathrm{ppm}$ for analysis. Multi-point calibration curves were made from dissolved standard solution with concentrations from 0 to $50 \mathrm{ppm}$ in the same acid matrix marked as the unknowns. Laboratory check standards were analyzed after measuring 6 or 12 samples, and the instrument was re-calibrated if check 
standards were not within $\pm 5 \%$ of the initial concentration. The instrument reproducibility $(\mathrm{n}=10)$ was determined using $1 \mathrm{mg} \mathrm{L}^{-1}$ elemental solutions ensuring $< \pm 2 \%$ error for all elements. The metal composition was expressed as atomic percentage of the elements in the nanoparticles.

The $\mathrm{Li}-\mathrm{O}_{2}$ battery performance measurement was performed using a SP-150 single-channel potentiostat and a VMP2 multichannel potentiostat (Biologic). Pure lithium foil (MTI, diameter of 15.6 $\mathrm{mm}$ and thickness of $0.25 \mathrm{~mm}$ and Alfa Aesar, ribbon, width of $19 \mathrm{~mm}$ and thickness of $0.75 \mathrm{~mm}$ ) was used as anode. The ink of catalysts for cathode was coated on a Celgard C480 separator (Celgard). In a custom-built cell, the measurement was carried out at room temperature using $1 \mathrm{M} \mathrm{LiPF} 6$ dissolved in tetraethylene glycol dimethyl ether (tetraglyme) as electrolyte. Cathodes with a Nafion/carbon weight ratio of $0.5 / 1$ were prepared by mixing the catalyst ink with Nafion dispersion (DE2020, ion-power) in 2propanol. The total carbon loading for each cathode (electrode area $=1.2 \mathrm{~cm}^{2}$ ) was $0.48 \pm 0.13 \mathrm{mg} \cdot \mathrm{cm}^{-2}$. For the assembly of the $\mathrm{Li}_{2} \mathrm{O}_{2}$ cell, a lithium foil was first placed on top of the stainless steel current collector followed by adding $15 \mu \mathrm{L}$ electrolyte. Two pieces of separator were placed on the lithium foil followed by adding $30 \mu \mathrm{L}$ electrolyte. A catalyst-inked Celgard was placed on the separator as the cathode followed by adding $5 \mu \mathrm{L}$ electrolyte. A current collector (316 SS mesh and spring) was then pressed on the cathode materials. The cell was sealed in a glovebox filled with pure argon, and then purged with DMC-saturated oxygen for $10 \mathrm{~min}$. The cell was tested galvanostatically at $0.12 \mathrm{~mA} \mathrm{~cm}{ }^{-2}$ between 2.0 and $4.5 \mathrm{~V}_{\mathrm{Li}}$.

Electrochemical impedance spectroscopic (EIS) measurements were performed on the assembled $\mathrm{Li}-\mathrm{O}_{2}$ cell using the potentiostat (Biologic). The measurement was performed at open circuit voltages (3.51 $\pm 0.4 \mathrm{~V}$ vs. Li) using an $\mathrm{AC}$ amplitude of $10 \mathrm{mV}$ in the frequency range from $100 \mathrm{kHz}$ to $0.1 \mathrm{~Hz}$.

Ab-initio calculations were carried out by DFT as implemented in DMol3 program coming as a part of Materials Studio suit of programs (Accelrys Inc.) [41,42]. In the calculations, the generalized gradient approximation (GGA) with the Becke-Lee-Yang-Parr (BLYP) exchange correlation functional was used $[43,44]$. The localized double numerical basis sets with polarization functions (DNP) were employed for 
the valence orbitals, and effective core potential was employed to account for the core electrons of metallic species. Full geometry optimizations were performed for all model atomic configurations tested here so that all atoms were fully relaxed. The configurations included unsupported small Pd-Cu clusters. The interactions between the model atomic configurations and $\mathrm{O}_{2}$ molecule were explored. The energy of adsorption of $\mathrm{O}_{2}$ on the model atomic configurations was used as a measure of the strength of $\mathrm{O}_{2}$ adsorption. It was calculated by $E_{\mathrm{ads}}=-\left(E_{\mathrm{O}_{2} \text {-metal }}-E_{\text {metal }}-E_{\mathrm{O}_{2}}\right)$, where $\mathrm{E}_{\mathrm{O}_{2}-\text { metal }}, E_{\mathrm{O}_{2} \text {-metal }}, E_{\text {metal }}$ and $E_{\mathrm{O}_{2}}$ are total energy for the $\mathrm{O}_{2}$-metal complex, the isolated metal cluster and the isolated $\mathrm{O}_{2}$ molecule, respectively [42].

\section{Results and Discussion}

\subsection{Nanoscale Alloying and Structural properties.}

The bimetallic composition of the as-synthesized $\mathrm{Pd}_{n} \mathrm{Cu}_{100-n}$ nanoparticles was analyzed using ICPOES technique. The approximate 1:1 ratio demonstrates that the binary composition can be well controlled [35]. Fig. 1 shows HAADF-STEM images from a sample of $\mathrm{Pd}_{21} \mathrm{Cu}_{79} / \mathrm{C}$ catalyst, which exhibits crystalline structure. The distributions of the two metal components are largely uniform across the nanoparticles, exhibiting some surface enrichment of Pd in a very thin layer along the alloyed surface. In addition certain amount of oxygen is also found in the NPs. Similar structural properties with subtle differences in lattice parameters were also observed for other alloy catalysts studied in this work.
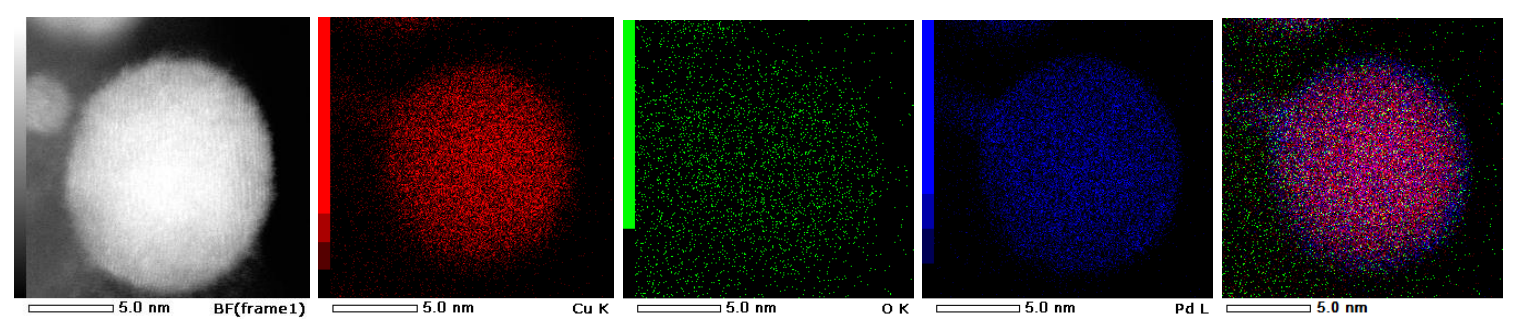

Fig. 1. High-angle annular dark field scanning TEM (HAADF-STEM) images: morphological imaging and elemental mapping for $\mathrm{Pd}_{21} \mathrm{Cu}_{79}$. 
High-energy XRD technique was recently used for studying of $\mathrm{Pd}_{n} \mathrm{Cu}_{100-\mathrm{n}} / \mathrm{C}$ NPs treated under $\mathrm{O}_{2}$ followed by $\mathrm{H}_{2}$ [36]. Fig. 2 shows a set of high-energy XRD patterns for $\mathrm{Pd}_{n} \mathrm{Cu}_{100-\mathrm{n}} / \mathrm{C}$ NPs treated under $\mathrm{N}_{2}$ at $260^{\circ} \mathrm{C}$ for $1 \mathrm{~h}$, followed by $\mathrm{H}_{2}$ at $400^{\circ} \mathrm{C}$ for $2 \mathrm{hrs}$. In Fig. 2(A), the patterns of $\mathrm{Pd}_{75} \mathrm{Cu}_{25} / \mathrm{C}$ and pure $\mathrm{Pd} / \mathrm{C}$ NPs resemble with each other to a large extent, as well as the pattern of $\mathrm{Pd}_{25} \mathrm{Cu}_{75} / \mathrm{C}$ NPs which indicates that all these three NPs are composed of single phase fcc structure. While the pattern of $\mathrm{Pd}_{50} \mathrm{Cu}_{50} / \mathrm{C}$ NPs displays extra peaks around $5^{\circ}$, implying the existence of a second phase. In Fig. 2(B), Experimental PDFs of pure $\mathrm{Pd} / \mathrm{C}, \mathrm{Pd}_{25} \mathrm{Cu}_{75} / \mathrm{C}$ and $\mathrm{Pd}_{75} \mathrm{Cu}_{25} / \mathrm{C}$ NPs are acquired through single phase fcc structure model. The experimental PDF of $\mathrm{Pd}_{50} \mathrm{Cu}_{50} / \mathrm{C}$ NPs is based on coexisting two phases structure. One of the phases is entirely chemical ordered structure featuring bcc-type. The other one, on the opposite, is completely chemical disordered characterized as fcc-type. The model fit lattice constant of all the NPs are also given in the figure. The lattice constant extracted from the HE-XRD data is plotted as a function of the bimetallic composition in Fig. 2(C). The lattice constant measured from HE-XRD/PDF data analysis showed $3.833,3.788$ and $3.697 \AA$ for the nanoalloys, all of which fall into the range between Pd and $\mathrm{Cu}(\mathrm{Pd} 3.859 \AA$ A, $\mathrm{Cu} 3.597 \AA$ ), suggesting that the nanoparticles were largely fully alloyed. As the composition of $\mathrm{Cu}$ increases, the lattice constant of $\mathrm{PdCu}$ NPs decreases. Since $\mathrm{Cu}$ atom is smaller than Pd atom, according to Vegard's law, when $\mathrm{Cu}$ accounts for a large amount in the nanoalloy, the lattice constant of $\mathrm{PdCu}$ will shrink respectively. $\mathrm{Pd}_{21} \mathrm{Cu}_{79}$ and $\mathrm{Pd}_{75} \mathrm{Cu}_{25}$ show single phase crystal structure of fcc-type when one of the metal in the binary nanoalloy is in dominant position. When the atomic composition of $\mathrm{Cu}$ and $\mathrm{Pd}$ is equal, the nanoalloy segregates into ordered bcc structure (red dot) and disordered fcc structure in $\mathrm{Pd}_{50} \mathrm{Cu}_{50}$. The phenomenon indicates that the $\mathrm{Pd}$ and $\mathrm{Cu}$ atoms in $\mathrm{PdCu}$ nanoalloy intend to form large atomic configurations with different crystalline structure instead of simply mechanical blending. The diversity of these atomic configurations and the distribution of atoms in the NPs are probably attributed to the post-synthesis thermochemical treatment. $\mathrm{PdCu}$ NPs could either distribute in clusters or core-shell structures with crystal structure in ordered bcc and disordered fcc. 


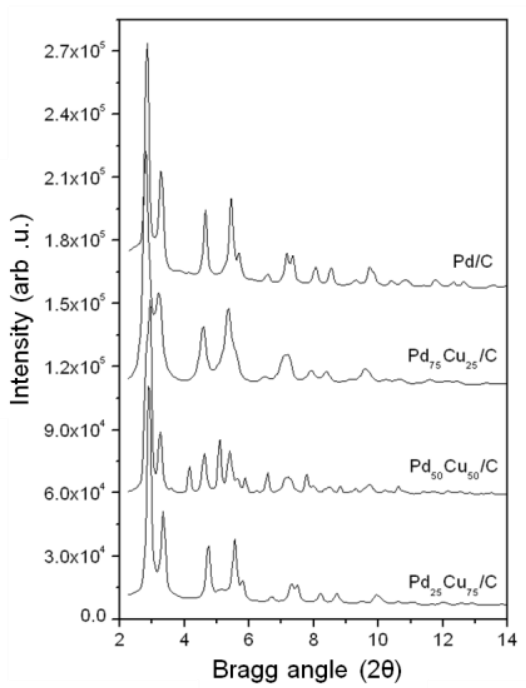

(A)

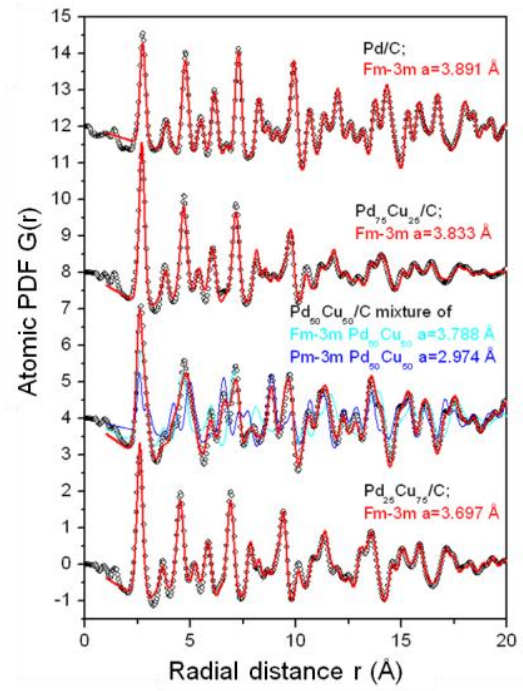

(B)

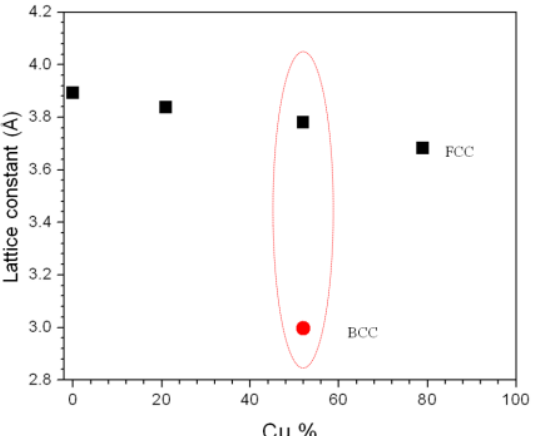

(C)

Fig. 2. (A) High energy XRD pattern of pure Pd and $\mathrm{Pd}_{n} \mathrm{Cu}_{100-\mathrm{n}} / \mathrm{C}$ NPs. (B) Atomic PDFs of model (red and blue lines) and experimental (symbols) data of pure $\mathrm{Pd} / \mathrm{C}$ and $\mathrm{Pd}_{\mathrm{n}} \mathrm{Cu}_{100-\mathrm{n}} / \mathrm{C}$ NPs. Experimental PDFs for pure $\mathrm{Pd}, \mathrm{Pd}_{75} \mathrm{Cu}_{25}$ and $\mathrm{Pd}_{21} \mathrm{Cu}_{79} \mathrm{NPs}$ are based on a model featuring a single nanophase with fcc-type (Space Group (S.G.): Fm-3m) structure. NP lattice parameters based on the atomic PDFs data are given by each data. The experimental PDF for $\mathrm{Pd}_{50} \mathrm{Cu}_{50}$ NPs can be approximated by a model featuring with one completely chemically disordered of an fcc-type (S.G. Fm-3m) structure, and the other phase is completely chemically ordered of a bcc-type (S.G. Pm-3m) structure. (C) Lattice constant from HE-XRD data analysis as a function of $\mathrm{Cu}$ composition in the alloy nanoparticles.

\section{2. $\mathrm{Li}-\mathrm{O}_{2}$ battery performance characteristics.}

A series of $\mathrm{Pd}_{n} \mathrm{Cu}_{100-\mathrm{n}} / \mathrm{C}$ catalysts were examined in a $\mathrm{Li}-\mathrm{O}_{2}$ cell with $1.0 \mathrm{M} \mathrm{LiPF} /$ tetraglyme electrolyte. Fig. 3(A) shows a representative set of discharge-charge curves of $\mathrm{PdCu} / \mathrm{C}$ catalysts with different bimetallic compositions in the $1^{\text {st }}$ cycle under current density of $0.12 \mathrm{~mA} \mathrm{~cm}^{-2}$. The data for $\mathrm{Pd} / \mathrm{C}$ and Carbon are also included for comparison. 


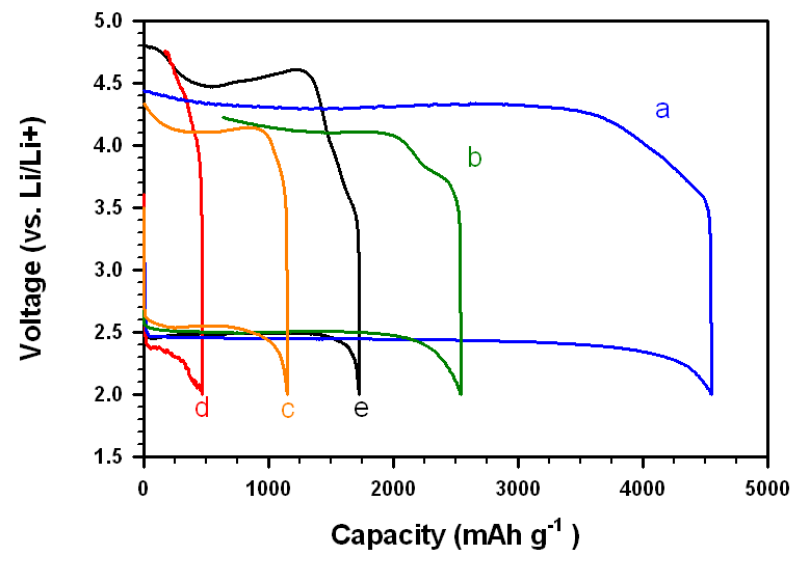

(A)

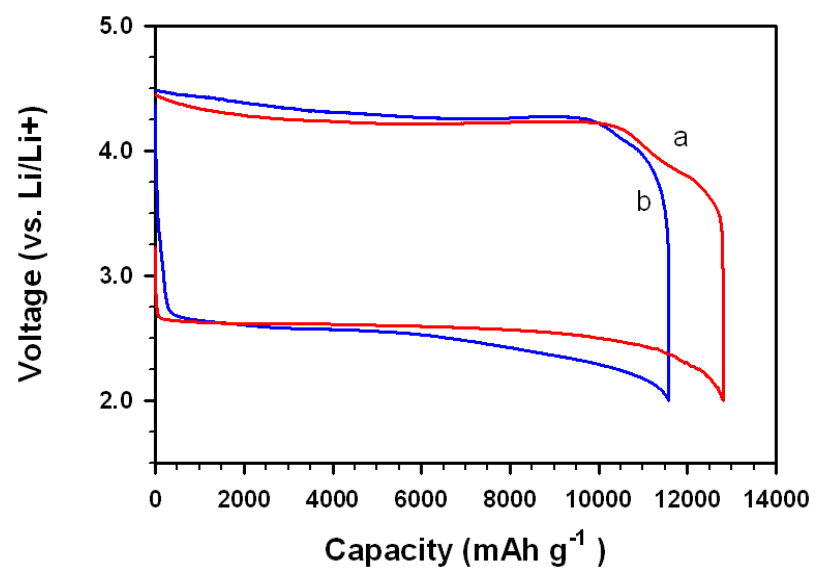

(B)

Fig. 3. (A) Comparison of discharge-charge curves for $\mathrm{PdCu} / \mathrm{C}$ catalysts with different binary compositions (a; blue: $\mathrm{Pd}_{21} \mathrm{Cu}_{79}$; b; green: $\mathrm{Pd}_{50} \mathrm{Cu}_{50}$; c; orange: $\mathrm{Pd}_{75} \mathrm{Cu}_{25}$ ). The data for commercial pure $\mathrm{Pd} / \mathrm{C}(\mathrm{d}$; red) and pure carbon catalyst (e; black) are included for comparison. Current density: $0.12 \mathrm{mAcm}^{-2}$ for ${ }^{\text {st }}$ cycle. Electrolyte in $\mathrm{Li}_{-} \mathrm{O}_{2}$ cell: $1.0 \mathrm{M} \mathrm{LiPF}_{6}$ in tetraglyme. (B) Discharge - charge curves for $\mathrm{Pd}_{21} \mathrm{Cu}_{79} / \mathrm{C}$ catalyst under an optimal cell configuration. Current density: (a) $0.12 \mathrm{~mA} \cdot \mathrm{cm}^{-2}$ for $1 \mathrm{st}$ cycle, red curve; (b) $0.06 \mathrm{~mA}$ $\mathrm{cm}^{-2}$ for 2 nd cycle, blue curve. Electrolyte in $\mathrm{Li}_{-} \mathrm{O}_{2}$ cell: $1.0 \mathrm{M} \mathrm{LiPF}_{6}$ in tetraglyme.

There are several important trends from this set of data in terms of the discharge-charge overpotentials and the discharge capacity. First, both the discharge-charge overpotentials and the discharge capacity are greatly improved by alloying $\mathrm{Pd}$ with $\mathrm{Cu}$ in comparison with $\mathrm{Pd}$ or Carbon alone, depending on the composition. Second, the discharge-charge overpotentials decrease, while relatively small, as the $\mathrm{Cu} \%$ decreases in the binary alloy. Third, the discharge capacity increases as the $\mathrm{Cu}$ ratio increases in the binary alloy, displaying an opposite trend compared with the discharge-charge overpotentials. It is intriguing that, depending on the configuration parameters of the cell, the increase of $\mathrm{Cu}$ in the binary composition shows a discharge capacity as high as $13,000 \mathrm{mAh} \cdot \mathrm{g}^{-1}$ (Fig. 3(B)), which is higher than previous studies with similar condition that have been reported [10,34]. Note that the condition for the assembly of the cell was found to be important for achieving the optimal performance of the catalyst, especially the degree of the reduction of moisture content in the dry box. The optimal performance for the given example was believed to be partially a result of lowering the moisture in the dry box for the cell assembly under our experimental condition. 
Finally, it also appears that the retention of the discharge capacity is greatly increased in alloy catalysts compared with $\mathrm{Pd} / \mathrm{C}$ and carbon materials, which showed 90 98\% retention. One exception is $\mathrm{Pd}_{53} \mathrm{Cu}_{47} / \mathrm{C}$ catalyst that showed $70 \%$ retention.

The effect of the composition on the discharge-charge overpotentials and the discharge capacity are further analyzed, as shown by a representative set of data shown in Fig. 4. Fig. 4(A) shows a plot of the discharge-charge voltages as a function of the bimetallic composition. The discharge voltage exhibits a maximum in the range of $25 \% \sim 50 \% \mathrm{Cu}$, closer to $\sim 25 \%$, whereas the charge voltage displays a minimum at the same composition. Note that for each composition of catalysts 3 4 samples were examined. The marker size in Fig. 4 represents the measurement error. Experimentally, while the absolute values showed a certain degree of variance from sample to sample, the overall trend remained unchanged, which is also supported by the data in Fig. 5. The sample variance was largely due to the difference in catalyst loading in the different sets of samples tested. Nevertheless, in each case, the overpotential exhibited an apparent minimum in overpotentials in the composition range of $20-50 \% \mathrm{Cu}$.

On the other hand, the discharge capacity shows a gradual increase when the $\mathrm{Cu}$ composition increases (Fig. 4(B)). The capacity of the catalyst with $25 \% \mathrm{Cu}$ is about two times higher than pure Pd. As $\mathrm{Cu} \%$ further increases to $80 \%$, the capacity increases by a factor about 10 . There is no significant decrease for the second cycle for most of the compositions tested except for 50\%, suggesting that the charge and discharge potentials are very sensitive to the composition change of $\mathrm{Pd}_{n} \mathrm{Cu}_{100-n}$ catalyst. Note that this is for the capacity values in which the data comparison was made within the same set of samples to illustrate the trend. 


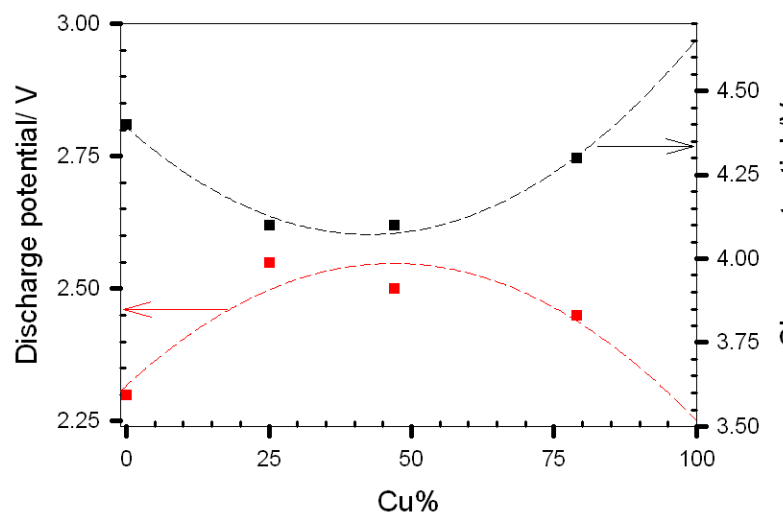

(A)

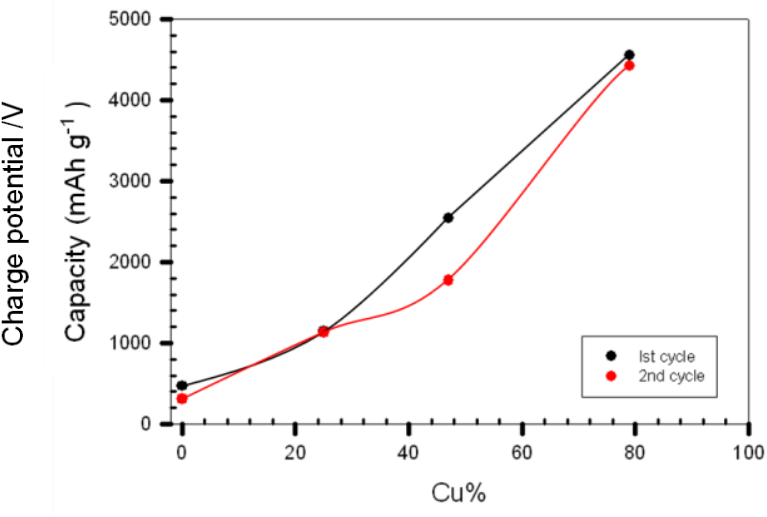

(B)

Fig. 4. Plots of (A) the discharge (red curve) and charge (black curve) potentials as a function of the bimetallic composition of $\mathrm{PdCu} / \mathrm{C}$ catalyst for the first cycle. The dashed lines serve as a guide to the eye to illustrate the overall trend; (B) Discharge capacity as a function of the bimetallic composition of $\mathrm{PdCu} / \mathrm{C}$ catalyst for the first and second cycle (Current density of 1 st cycle is $0.12 \mathrm{~mA} \cdot \mathrm{cm}^{-2}, 2^{\text {nd }}$ is $0.06 \mathrm{~mA} \cdot \mathrm{cm}^{-2}$.

\subsection{Charge-discharge characteristics under different current densities}

Catalysts with different compositions of $\mathrm{PdCu}$ were also tested in the cell under different current densities. The cells were first charged to $200 \mathrm{~mA} \cdot \mathrm{h} \mathrm{g}^{-1}$ capacity at different current densities (see Fig. S1). As the current density increases, the overall potential of the cells also increases. Compared with lower current density, the overall potential at higher current density tends to increase more significantly. The subtle differences in the change of discharge potential and charge potential imply that catalyst could strongly affect the ORR activity.

When the composition of the $\mathrm{Pd}_{n} \mathrm{Cu}_{100-n}$ nanoalloys varies, the charge and discharge potentials also change at different current densities (Fig. 5). A volcano-type feature of charge-discharge potentials as a function of $\mathrm{Cu}$ composition is displayed. Fig. 5(A) shows that a maximum of discharge potential appeared around $25 \sim 50 \% \mathrm{Cu}$. As the current density increases, the peak shifts to 50\% $\mathrm{Cu}$. In Fig. 5(B), a minimum value of the charge potential appeared at $25 \% \mathrm{Cu}$ under lower current density $\left(\leq 20 \mathrm{~mA} \cdot \mathrm{g}^{-1}\right)$. When current density increases, a lower point occurs at $50 \% \mathrm{Cu}$. The bimetallic composition apparently plays an important role in the change of discharge and charge potentials. In a previous DFT calculation [45], it 
showed that when atomic ratio of $\mathrm{Pd}: \mathrm{Cu}$ is $1: 1$, the binding energy is the highest. As an indicator of ORR activity, it could be attributed to the d-band center shift of Pd and $\mathrm{Cu}$ imposed on each other.

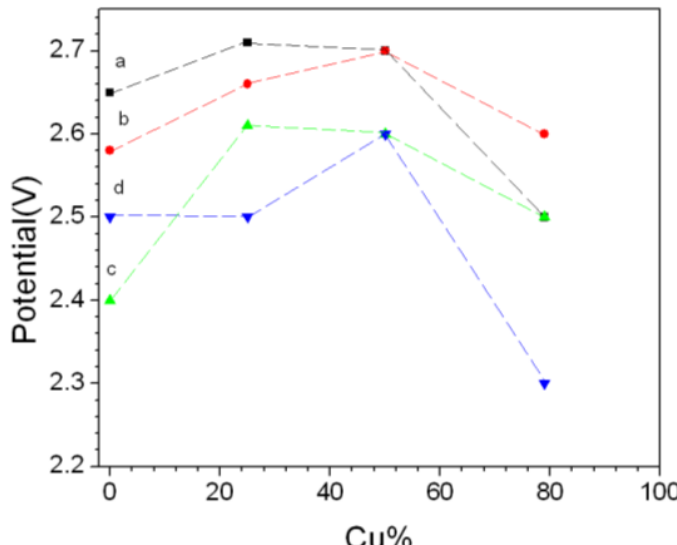

(A)

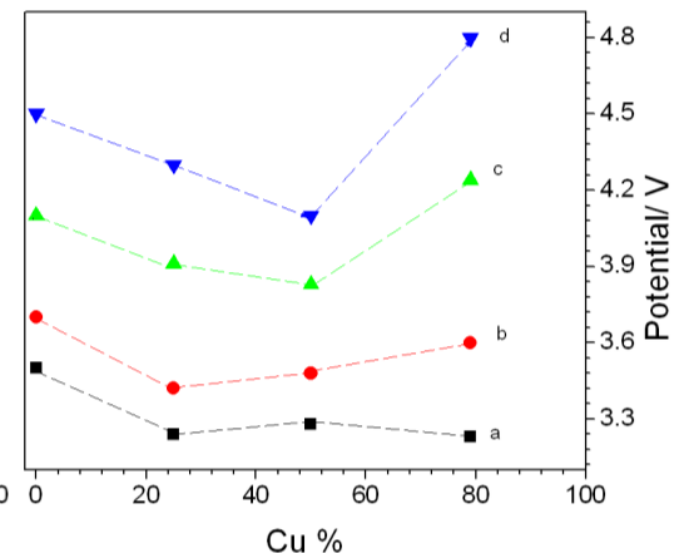

(B)

Fig. 5. (A) Discharge and (B) charge potentials against composition of catalysts at various current density. Current density: (a) $10 \mathrm{~mA} \cdot \mathrm{g}^{-1}$, black; (b) $20 \mathrm{~mA} \cdot \mathrm{g}^{-1}$, red; (c) $40 \mathrm{~mA} \cdot \mathrm{g}^{-1}$, green; (d) $76 \mathrm{~mA} \cdot \mathrm{g}^{-1}$, blue. All the cells have been pre-charged to $200 \mathrm{~mA} \cdot \mathrm{h} \cdot \mathrm{g}^{-1}$. The dashed lines serve as a guide to the eye to illustrate the overall trend.

Our results seem to be consistent with a previous report [46] which showed that the molar ratios of $\mathrm{PdCu}$ at 1:1 and 1:3 with smaller particle sizes could enhance the ORR activity. Some reports also showed the influence of different electrode materials on discharge potential, such as $\mathrm{Au}, \mathrm{Pt}$ and metal oxides $\left(\alpha-\mathrm{MnO}_{2}, \mathrm{Fe}_{2} \mathrm{O}_{3}\right)$, and the instability of carbon-based electrolyte because of superoxide $\left(\mathrm{O}_{2}^{-}\right)$[47]. Since ether-based electrolyte is proved to be more stable, and the $\mathrm{O}_{2} / \mathrm{O}_{2}{ }^{-}$shows reversibility in the electrolyte, the increase of the discharge potential in our experiment indicates catalysts could strongly enhance the OER activity.

\subsection{Impedance characterization.}

The possibility of electrolyte decomposition during the discharge-charge processes has also been studied using electrochemical impedance spectroscopy. In the discharge-charge processes of $\mathrm{Pd}_{21} \mathrm{Cu}_{79} / \mathrm{C}$ catalyst (Fig. 6(A)), the impedance spectra were obtained, which are presented in Nyquist plots as a function of state of charge (SOC) or depth of discharge (DOD) (Fig. 6(B)). 


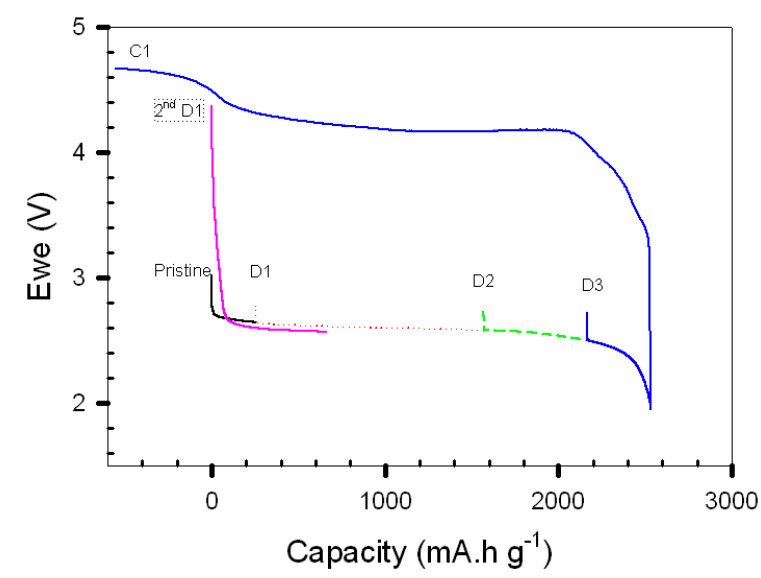

(A)

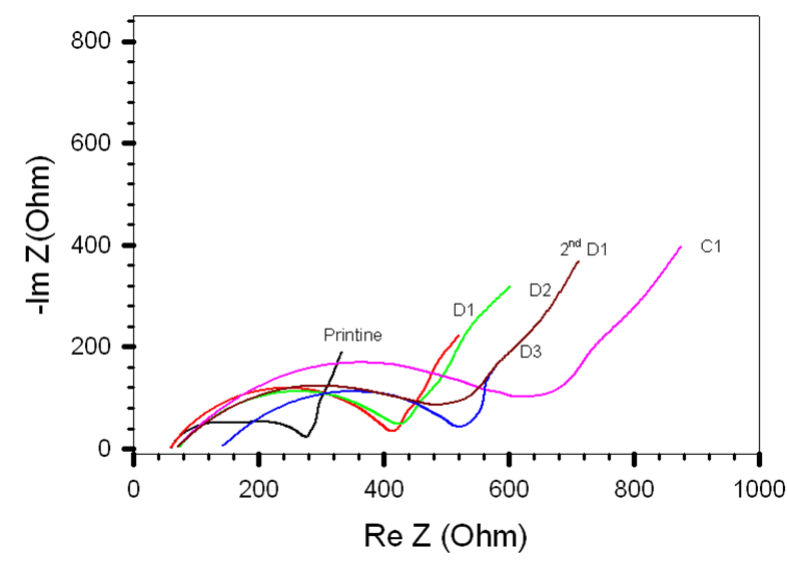

(B)

Fig. 6. (A) Discharge-charge curves of cell with $\mathrm{Pd}_{21} \mathrm{Cu}_{79} / \mathrm{C}$ catalyst (current density: $0.12 \mathrm{~mA} / \mathrm{cm}^{2}$ ) (B) Nyquist plots as a function of state of charge (SOC) or depth of discharge (DOD) (pristine; D1: 0.10 discharge; D2: 0.66 discharge; D3: 0.91 discharge; C1: 100\% Charge; $2^{\text {nd }} \mathrm{D} 1$ : second cycle 0.28 discharge) for a cell with catalyst $\mathrm{Pd}_{21} \mathrm{Cu}_{79} / \mathrm{C}$.

As a qualitative assessment of the charge transfer and interfacial properties, the data were analyzed using an ideal equivalent circuit with a series combination of resistor in the electrolyte $\left(\mathrm{R}_{\Omega}\right)$ and a parallel combination of double-layer capacitance $\left(\mathrm{C}_{\mathrm{dl}}\right)$ with impedance $\left(\mathrm{Z}_{\mathrm{F}}\right)$. The impedance $\mathrm{Z}_{\mathrm{F}}$ could be simplified as charge transfer resistance $\left(\mathrm{R}_{\mathrm{t}}\right)$ under certain conditions [48]. It is important to note that there is no well-developed impedance model for the operating battery cell due to the double layer complications on the counter electrode, since most models are for the three electrodes system. As such, the discussion here only serves as a qualitative assessment of the data in relation to the charge-discharge processes and electrolyte decomposition. By curve fitting using the model provided, resistance and capacitance values are obtained (Table S1) [49]. A comparison of the general features at different state of charge (SOC) or depth of discharge (DOD) provides some useful information. In comparison with data for the fresh state, which clearly contains a high-frequency semi-circle overlapped with the middlefrequency circle, the discharged state shows an increased charge transfer resistance. As DOD increases (e.g., 0.10, 0.66, and 0.91 DOD), the charge transfer resistance increases with little change in the resistance of the surface, reflecting the formation of $\mathrm{Li}_{2} \mathrm{O}_{2}$ layer. After fully charged, the resistance of the 
surface shows a clear increase while the charge transfer resistance is decreased. The former indicates the formation of a layer on the surface from the product of the electrolyte decomposition, whereas the latter reflects the release of $\mathrm{Li}_{2} \mathrm{O}_{2}$. Interestingly, for the $2^{\text {nd }}$ discharge at $0.28 \mathrm{DOD}$, the return of the surface film resistance implies the removal of the surface film as new $\mathrm{Li}_{2} \mathrm{O}_{2}$ layer formed. However, the charge transfer resistance did not show a complete return, suggesting that the solid electrolyte interface (SEI) morphology (e.g., clogging of pores) [50] of the newly deposited $\mathrm{Li}_{2} \mathrm{O}_{2}$ likely differs from that in the first discharge.

A more detailed impedance analysis was performed at different depths or states (Fig. 7(A). Since the semicircle of the Nyquist plot also indicates the internal resistance, resistance value could be determined at different stages of charge and discharge. In Fig. 7(B), the internal resistance shows an increase as the discharge deepens. Since the frequency is decreased from left to right, the semicircle shifts to the lower frequency side when discharge completes. In Fig. 7(C\&D), there is an obvious change when charge starts. At the transition point, it reveals a much smaller resistance compared with that taken just after the last charge. When charging over the initial capacity by $50 \%$, the semicircle of the impedance shifts to higher frequency side until fully charged, which is very close to initial charge state. When overcharged, the semicircle of impedance experiences a high frequency shift followed by a low frequency shift.

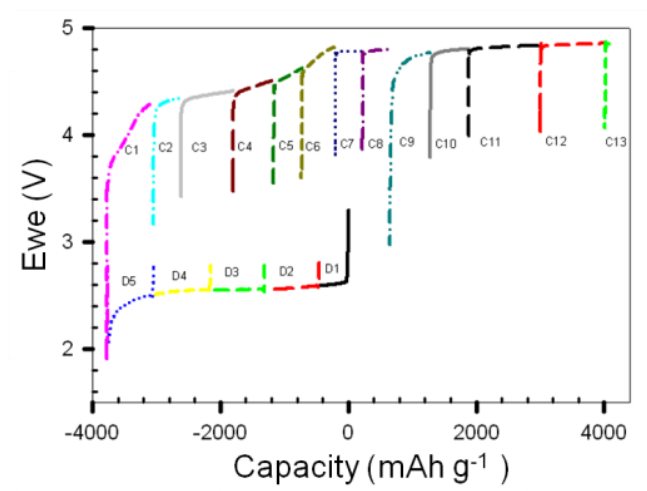

(A)

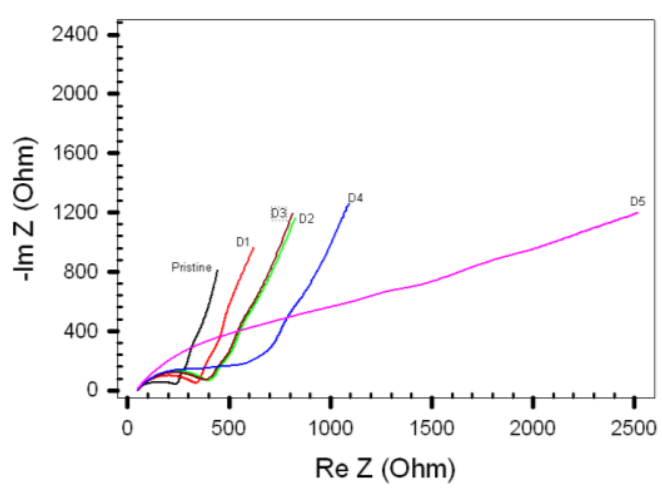

(B) 


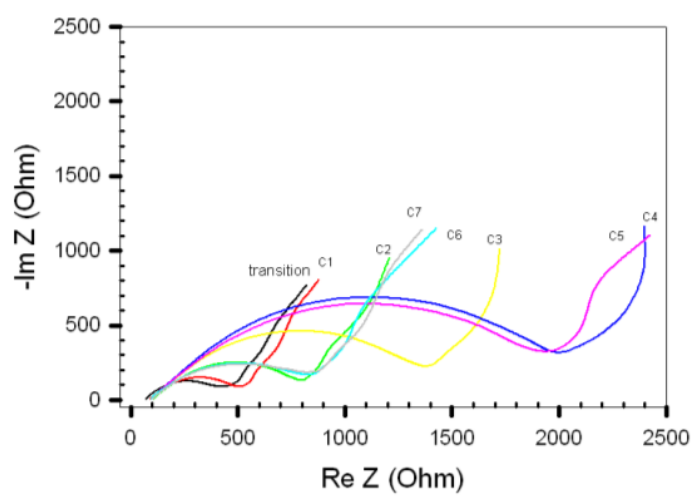

(C)

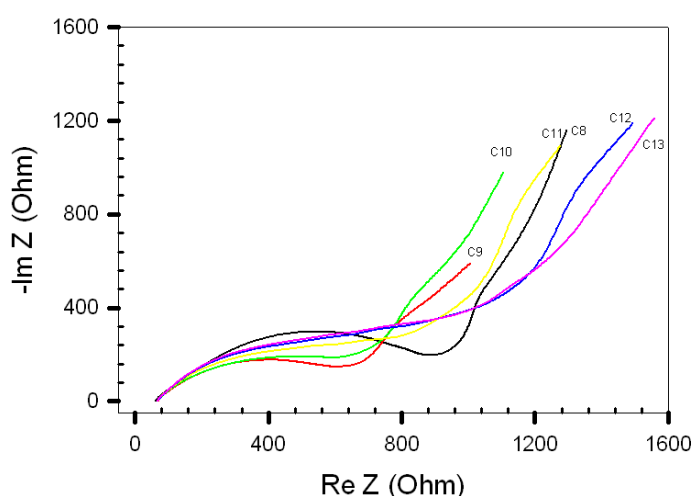

(D)

Fig. 7. (A) Discharge-charge curves for $\mathrm{Pd}_{21} \mathrm{Cu}_{79} / \mathrm{C}$ catalyst (current density: $0.12 \mathrm{~mA} \cdot \mathrm{cm}^{-2}$ ). (B) Nyquist plots as a function of depth of discharge (DOD) (D1-D5: discharge 12\%, 35\%, 57\%, 81\%, 100\% of DOD). (C\&D) Nyquist plots as a function of state of charge (SOC) (C1-C13: charge 19\%, 31\%, 52\%, 69\%, 81\%, $94 \%, 106 \%, 117 \%, 134 \%, 150 \%, 179 \%, 206 \%, 210 \%$ of SOC; transition point refers to discharge switch to charge).

Further qualitative assessments were based on analysis of the equivalent circuit of resistance and capacitance (see Fig. S2). The internal resistances in discharge and charge processes show a major change at 0.7 DOD or SOC (Fig. S2 (A)). There is a sharp increase at about $70 \%$ of charge, after which it decreases to a point near $100 \%$ of charge before showing fluctuation or some increase when overcharged. For the capacitance (Fig. S2(B)), it shows a tendency of increase when discharging up to $\sim 80 \%$ before dropping when fully discharged. The capacitance is relatively flat until overcharged at $120 \%$. A dramatic increase is evidenced up to $180 \%$ of SOC. After a mildly decrease, a maximum capacitance is achieved at $210 \%$ of SOC. The increase of resistance in discharge and charge reflects the interfacial reactivity, whereas the sudden drop at discharge could be attributed to the formation of SEI layer [51]. During charging, the nonconductive product $\mathrm{Li}_{2} \mathrm{O}_{2}$ deposits on the electrode, which contributes to the increase of resistance. It decreases as $\mathrm{Li}_{2} \mathrm{O}_{2}$ decomposes. The phenomenon has been interpreted as the formation of cycling product on the electrolyte/electrode interface in previous report [52].

\subsection{Discussion of the catalytic synergy}

These findings are suggestive of the operation of an intriguing synergy by a combination of the ensemble and ligand effects as a result of the bimetallic alloying. The surface catalytic sites play an 
important role in activating $\mathrm{O}_{2}$ and maneuvering the resulting superoxide/peroxide species on the catalyst surfaces. The results also seem to be in a qualitative agreement with a recent computational modeling result [38], which suggested that the $\mathrm{O}_{2}$ adsorption energy depends on the bimetallic composition, displaying an optimal composition $(30 \% \mathrm{Cu})$ for the adsorption of $\mathrm{O}_{2}$ in $\mathrm{ORR}$. Based on the observation that both lowest $\mathrm{O}_{2}$ adsorption and the highest $\mathrm{OH}$ adsorption energy occurs at $\sim 30 \% \mathrm{Cu}$ in the $\mathrm{PdCu}$ (i.e., $\mathrm{Pd}_{3} \mathrm{Cu}$ alloy), it is suggested that alloying around $30 \% \mathrm{Cu}$ may reduce significantly the formation of $\mathrm{OH}$ species ("poisons") on the $\mathrm{Pd}$ surface sites, which release the $\mathrm{Pd}$ sites for $\mathrm{O}_{2}$ adsorption. The repulsion between $\mathrm{OH}$ species on the $\mathrm{Cu}$ sites and on the Pd sites decreases the coverage of $\mathrm{OH}$ on the $\mathrm{Pd}$.

Part of the synergistic effect of the copper metal can also be interpreted by considering oxophilicity of the nanoalloy. Copper is known for its oxophilicity depending on the oxidation states. Our recent work on oxygen activation for $\mathrm{AuCu}$ nanoalloy catalysts [7, 43] showed that the catalytic properties depend on the degree of alloying and bimetallic composition. Considering the reduction potentials for oxygenated metal species $\left(\mathrm{M}(\mathrm{OH})_{\mathrm{x}}\right.$ or $\left.\mathrm{MO}_{\mathrm{x}}\right)$ in base electrolytes [35], there is a subtle difference between $\mathrm{Pd}$ and $\mathrm{PdCu}$. For Pd, the peak observed at $-0.37 \mathrm{~V}$ is considered to originate from the reduction of the $\mathrm{Pd}-\mathrm{OH}$ ad species. The reduction potential for $\mathrm{PdCu}(-0.34 \mathrm{~V})$ is more positive than $\mathrm{Pd}(-0.37 \mathrm{~V})$, suggesting that alloying $\mathrm{Pd}$ with $\mathrm{Cu}$ favors the reduction of $\mathrm{PdO}_{\mathrm{X}}$.

Mechanistically, the formation of superoxide/peroxide involves the reduction of $\mathrm{O}_{2}$ on $\mathrm{Pd}$ to form $\mathrm{Pd}-\left(\mathrm{O}_{2}^{2-}\right)$ ads, and further reacting with $\mathrm{Li}^{+}$, forming $\mathrm{LiO}_{2}{ }^{-}$species:

$$
\begin{aligned}
& \text { Pd }-\left(\mathrm{O}_{2}\right)_{\text {ads }}+2 e^{-} \rightarrow \mathrm{Pd}-\left(\mathrm{O}_{2}{ }^{2-}\right)_{\text {ads }} \\
& \mathrm{Pd}-\left(\mathrm{O}_{2}{ }^{2-}\right)_{\text {ads }}+\mathrm{Li}^{+} \stackrel{\text { r.d.s }}{\longrightarrow} \mathrm{Pd}-(\mathrm{O}-\mathrm{O}-\mathrm{Li})^{-}
\end{aligned}
$$

A possible transfer of $\mathrm{LiO}_{2}^{-}$from $\mathrm{Pd}-\left(\mathrm{LiO}_{2}{ }^{-}\right)_{\text {ads }}$ site to $\mathrm{Cu}$ site would facilitate the formation of $\mathrm{Cu}-\left(\mathrm{LiO}_{2}{ }^{-}\right)$ species, leaving Pd site available for adsorption of $\mathrm{O}_{2}$ :

$$
\mathrm{Pd}-(\mathrm{O}-\mathrm{O}-\mathrm{Li})^{-}+\mathrm{Cu} \stackrel{\text { r.d.s }}{\longrightarrow} \mathrm{Cu}-(\mathrm{O}-\mathrm{O}-\mathrm{Li})^{-}+\mathrm{Pd}
$$


This possibility depends on the oxophilicity of $\mathrm{Cu}$ site and the relative difference of redox potentials between these sites. Based on the reduction potentials for $\mathrm{Pd}$ and $\mathrm{Cu}$ species such as $\mathrm{PdO}, \mathrm{Pd}(\mathrm{OH})_{2}, \mathrm{CuO}$, $\mathrm{Cu}(\mathrm{OH})_{2}$, etc, the reduction potential of $\mathrm{Pd}(\mathrm{OH})_{2}$ is greater than that of $\mathrm{Cu}(\mathrm{OH})_{2}$ in alkaline electrolytes [39,40,53]. $\mathrm{Cu}$ alloyed with $\mathrm{Pd}$ may have the ability to transfer $\mathrm{OH}_{\mathrm{ads}}$ between $\mathrm{Pd}$ and $\mathrm{Cu}$ sites, thus facilitating the removal of $\mathrm{OH}_{\mathrm{ads}}$ species in the ORR. The fact that $\mathrm{PdCu}$ with $30 \% \mathrm{Cu}$ has the lowest $\mathrm{O}_{2}$ adsorption and the highest $\mathrm{OH}$ adsorption energy [25] may be partially responsible for the ability of releasing the $\mathrm{Pd}$ sites for $\mathrm{O}_{2}$ adsorption by removing $\mathrm{OH}$ on $\mathrm{Pd}$ through the alloyed $\mathrm{Cu}$ sites.

From catalytic and surface refreshing perspectives, it is desired that the oxophilicity is neither too weak nor too strong, so that the superoxide/peroxide species can easily be maneuvered around the catalytic sites. This ability favors not only the formation of the superoxide/peroxide species in the discharge process, but also the reoxidation in the charge process. In an analogy to catalytic CO oxidation on $\mathrm{PdCu}$ [36], Scheme 1 illustrates possible pathways for the formation and maneuvering of $\mathrm{O}_{2}^{2-}$ ads species in discharge-charge processes on different crystal planes ((100), (110) and (111)) of the bcc and fcc types of structures.

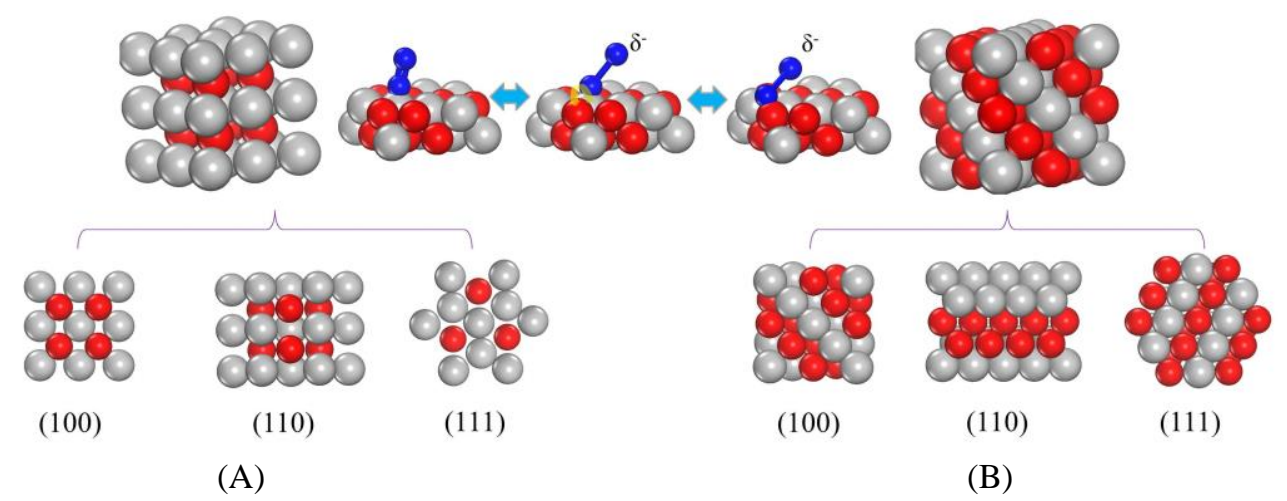

Scheme 1. Intermixing of $\mathrm{Pd}$ (grey) and $\mathrm{Cu}(\mathrm{red})$ atoms on different crystal plane of (A) bcc and (B) fcc structures of $\mathrm{PdCu}$ nanoalloy. Each $\mathrm{Cu}$ atom has $8 \mathrm{Pd}$ atoms as first neighbor, and so does Pd. Intermixing of $\mathrm{Pd}$ and $\mathrm{Cu}$ atoms on different crystal plane of fcc structures of. $\mathrm{Pd}$ and $\mathrm{Cu}$ atoms occupy the vertices of a cell randomly. Middle inset: illustration of the adsorption of $\mathrm{O}_{2}$ (blue) on $\mathrm{PdCu}$ catalyst (111) plane and the formation and maneuvering of $\mathrm{O}_{2}{ }^{2-}$ ads species in the discharge-charge processes. 
$\mathrm{Pd}$ and $\mathrm{Cu}$ atoms on are clearly more intermixed in fcc phase than that in bcc phase, which leads to an ensemble effect favoring the formation and maneuvering of $\mathrm{O}_{2}{ }^{2-}$ ads species. The bimetallic composition and crystal structure have a strong effect on the structural and catalytic characteristics

A preliminary DFT calculation of the adsorption energy of oxygen was also performed to assess the composition dependence (Fig. S3). The lowest oxygen adsorption energy is found to appear at $25 \% \mathrm{Cu}$ which is similar to the results reported previously [38]. The catalyst with $25 \% \mathrm{Cu}$ shows higher activity than the other compositions. The interactions between transition metal and oxygen are mainly composed of three types: side-on, end-on, and bridge [24]. The end-on type is usually found in the reaction of $\mathrm{Li}^{-\mathrm{O}_{2}}$ battery, which is different from the bridge type utilized in other reactions [38,54]. The change in bond length of $\mathrm{O}-\mathrm{O}$ bond and $\mathrm{O}-\mathrm{Pd}$ bond is shown in Fig. $\mathrm{S} 3$ (B). For $\mathrm{Cu}<50 \%$, there is an increase of O-O bond and a decrease of $\mathrm{O}-\mathrm{Pd}$ bond length. On the other hand, for $\mathrm{Cu}>50 \%$, the $\mathrm{Cu}-\mathrm{O}$ interaction is favored [55]. This may be responsible for an increased ORR activity. Strong oxygen adsorption hinders the ORR kinetics, whereas intermediate oxygen adsorption energy could increase the ORR activity [56]. A more in-depth DFT calculation is required to fully understand how $\mathrm{Cu}$ affects the d-band shift, which is part of our on-going work.

\section{Conclusion}

In summary, the results have demonstrated a significant influence of synergy effect of $\mathrm{PdCu}$ catalysts on the electrocatalytic properties in a rechargeable $\mathrm{Li}-\mathrm{O}_{2}$ battery. The nanoalloys are characterized by fcc and bcc nanophases depending on the bimetallic composition. The nanoalloy with an atomic ratio near 50:50 features a mixed bcc and fcc structures, whereas the catalysts with other compositions are characterized by fcc structure [36]. The nanoalloy in the composition range of 20 50\% $\mathrm{Cu}$, closer to $25 \% \mathrm{Cu}$, is shown to exhibit a maximum reduction of the discharge or charge overpotentials. The synergy of the nanoalloy in affecting the overpotentials is believed to be associated with a combination of ensemble and ligand effects, including the activation of oxygen on Pd sites and the oxygen oxophilicity or oxygen storage capacity of the alloyed $\mathrm{Cu}$ sites in the catalyst. This synergy 
allows the catalytic sites for effectively activating oxygen and maneuvering surface superoxide/peroxide species on the surface. A more detailed study is needed to correlate the phase structures with charge/discharge capacity. The findings have implications for designing catalysts with a balanced catalytic activation and oxophilicity to facilitate the deposition and maneuvering of lithium peroxide species on the catalyst during discharge-charge processes.

Acknowledgement: The work was supported by NYSERDA-NYBEST (\# 18514), and in part by the NSF Grant (CMMI 1100736) and the DOE-BES Grant (DE-SC0006877). 


\section{References:}

1. J. Xiao, D. Mei, X. Li, W. Xu, D. Wang, G. L. Graff, W. D. Bennett, Z. Nie, L. V. Saraf, I. A. Aksay, J. Liu, J. G. Zhang, Nano. Lett. 11 (2011) 5071-5078.

2. J. R. Harding, Y. C. Lu, Y. Tsukada, Shao-Horn. Yang, Phys. Chem. Chem. Phys. 14 (2012) 10540-10546.

3. J. Christensen, P. Albertus, R. S. Sanchez-Carrera, T. Lohmann, B. Kozinsky, R. Liedtke, J. Ahmed, A. Kojica, J. Electrochem. Soc. 159 (2012) R1-R30.

4. H. G. Jung, Y. S. Jeong, J. B. Park, Y. K. Sun, B. Scrosati, Y. J. Lee, ACS. Nano. 7 (2013) 35323539.

5. Y. Tian, H. Yue, Z. Gong, Y. Yang, Electrochim. Acta 90 (2013) 186-193.

6. K. M. Abraham, Z. Jiang, J. Electrochem. Soc. 143 (1996) 1-5.

7. W. Xu, J. Xiao, D. Wang, J. Zhang, J. G. Zhang, J. Electrochem. Soc. 157 (2010) A219-A244.

8. T. Ogasawara, A. Debart, M. Holzapfel, P. Novak, P. G. Bruce, J. Am. Chem. Soc. 128 (2006) 1390-1393.

9. S. A. Freunberger, Y. Chen, Z. Peng, J. M. Griffin, L. J. Hardwick, F. Bard, P. Novak, P. G. Bruce, J. Am. Chem. Soc. 133 (2011) 8040-8047.

10. S. A. Freunberger, Y. Chen, N. E. Drewett, L. J. Hardwick, F. Bard, P. G. Bruce, Angew. Chem. Int. Ed. 50 (2011) 8609-8613.

11. Z. Peng, S. A. Freunberger, L. J. Hardwick, Y. Chen, V. Giordani, F. Barde, P. Novak, D. Graham, J. M. Tarascon, P. G. Bruce, Angew. Chem. Int. Ed. 50 (2011) 6531-6555.

12. D. Sun, Y. Shen, W. Zhang, L. Yu, Z. Yi, W. Yin, D. Wang, Y. Huang, J. Wang, D. Wang, J. B. Goodenough, J. Am. Chem. Soc. 136 (2014) 8941-8946.

13. A. Dbart, A. J. Paterson, J. Bao, P. G. Bruce, Angew. Chem. Int. Ed. 47 (2008) 4521-4524.

14. A. Debart, J. Bao, G. Armstrong, P. G. Bruce, J. Power Sources 174 (2007) 1177-1182.

15. F. Jiao, J. Bao, P. G. Bruce, Electrochem. Solid-State Lett. 10 (2007) A264-A266.

16. A. Débart, J. Bao, G. Armstrong, P. G. Bruce, ECS Transactions 3 (2007) 225-232.

17. J.K. Ngala, S. Alia, A. Dobley, V.M.B. Crisostomo, S.L. Suib, Chem. Mater. 19 (2007) 229-234.

18. M. Vucinic-vasic, B. Antic, J. Blanusa, S. Rakic, A. Kremenovic, A.S. Nikolic, A. Kapor, Appl. Phys. A 82 (2006) 49-54.

19. Y. C. Lu, Z. Xu, H. A. Gasteiger, S. Chen, K. Hamad-Schifferli, S-H. Yang, J. Am. Chem. Soc. 132 (2010) 12170-12171.

20. Y. C Lu, H. A. Gasteiger, E. Crumlin, R. McGuire Jr., S-H. Yang, J. Electrochem. Soc. 157 (2010) A1016-A1025.

21. Y. C Lu, H. A. Gasteiger, M. C. Parent, V. Chiloyan, S-H. Yang, Electrochem. Solid-State Lett. 13 (2010) A69-A72.

22. J. Yin, B. Fang, J. Luo, B. Wanjala, D. Mott, R. Loukrakpam, M. S. Ng, Z. Li, J. Hong, M. S. Whittingham, C. J. Zhong, Nanotechnology 23 (2012) 305404. 
23. W. H. Ryu, T. H. Yoon, S. H. Song, S. Jeon, Y. J. Park, I. D. Kim, Nano. Lett. 13 (2013) 41904197.

24. J. Zhang. PEM fuel cell electrocatalysts and catalysts layers: fundamentals and applications. 2008. DOI.10.1007/978-1-84800-936-3.

25. G. Girishkumar, B. McCloskey, A. C. Luntz, S. Swanson, W. J. Wilcke, Phys. Chem. Lett. 1 (2010) 2193-203.

26. J. Luo, L. Wang, D. Mott, P. Njoki, Y. Lin, T. He, Z. Xu, B. Wanjana, I-Im. S. Lim, C. J. Zhong, Adv. Mater. 20 (2008) 4342-4347.

27. J. Luo, P. Njoki, Y. Lin, L. Wang, D. Mott, C. J. Zhong, Electrochem. Comm. 8 (2006) 581-587.

28. J. Luo, P. Njoki, Y. Lin, D. Mott, L. Wang, C. J. Zhong, Langmuir 22 (2006) 2892-2898.

29. D. Mott, J. Luo, A. Smith, L. Wang, P. N. Njoki , C. J. Zhong, Nanoscale. Res. Lett. 2 (2006) 1216.

30. D. Mott, J. Luo, P. Njoki, Y. Lin, L. Wang, C. J. Zhong, Catal. Today 122 (2007) 378-385.

31. B. Wanjala, J. Luo, B. Fang, D. Mott, C. J. Zhong, Mater. Chem. 21 (2011) 4012-4020.

32. B. N. Wanjala, J. Luo, R. Loukrakpam, D. Mott, P. N. Njoki, B. Fang, M. Engelhard, H. R. Naslund, J. K. Wu, L. Wang, O. Malis, C. J. Zhong, Chem. Mater. 22 (2010) 4282-4294.

33. J. Luo, M. M. Maye, V. Petkov, N. N. Kariuki, L. Wang, P. Njoki, D. Mott, Y. Lin, C. J. Zhong, Chem. Mater. 17 (2005) 3086-3091.

34. R. Choi, J. Jung, G. Kim, K. Song, Y. Kim, S. C. Jung, Y. K. Han, H. Song, Y. M. Kang, Energy Environ. Sci. 7 (2014) 1362-1368.

35. J. Yin, S. Shan, M. S. Ng, L. Yang, D. Mott, W. Fang, N. Kang, J. Luo, C. J. Zhong, Langmuir 29 (2013) 9249-9258.

36. S. Shan, V. Petkov, B. Prasai, J. Wu, P. Joseph, Z. Skeete, E. Kim, D. Mott, O. Malis, J. Luo, C. J. Zhong, Nanoscale 7 (2015) 18936-18948.

37. A. Serov, U. Martinez, A. Falase, P. Atanassov, Electrochem. Comm. 22 (2012) 193-196.

38. F. Fouda-Onana, O. Savadogo, Electrochim. Acta 54 (2009) 1769-1776.

39. J. Luo, L. Han, N. Kariuki, L. Wang, D. Mott, C. J. Zhong, T. He, Chem. Mater. 17 (2005) 52825290.

40. J. Luo, M. M. Maye, V. Petkov, N. N. Kariuki, L. Wang, P. Njoki, D. Mott, Y. Lin, C. J. Zhong, Chem. Mater. 17 (2005) 3086-3091.

41. M. R. Xia, W. Ding, K. Xiong, L. Li, X. Q. Qi, S. G. Chen, B. S. Hu, Z. D. Wei, J. Phys. Chem. C 117 (2013) 10581-10588.

42. C. R. Chang, Y. G. Wang, J. Li, Nano. Res. 4 (2011) 131-142.

43. L. Wang, Y. Wang, S. Q. Song, P. K. Shen, Chinese J. Catalysis 30 (2009) 433-439.

44. W. J. Tang, L. Zhang, G. J. Henkelman, Phys. Chem. Lett. 2 (2011) 1328-1331. 
45. W. Tang, L. Zhang, G. Henkelman, J. Phys. Chem. Lett. 2 (2011) 1328-1331.

46. N. N. Kariuki, X. Wang, J. R Mawdsley, M. S. Ferrandon, S. G. Niyogi, J. T. Vaughey, D. J. Myers, Chem. Mater. 22 (2010) 4144-4152.

47. Y. C Lu, B. M. Gallant, D. G. Kwabi, J. R. Harding, R. R. Mitchell, M. S. Whittingham, S. H. Yang, Energy. Environ. Sci. 6 (2013) 750-768.

48. M. Mehta, G. Mixon, J. P. Zheng, P. Andrei, J. Electrochem. Soc. 160 (2013) A2033-A2045.

49. G. Ning, B. Haran, B. N. Popov, J. Power Sources 117 (2003) 160-169.

50. L. Wang, M. Ara, K. Wadumesthrige, S. Salley, K. Y. S. Ng, J. Power Sources 234 (2013) 8-15.

51. L. Grande, E. Paillard, G. T. Kim, S. Monaco, S. Passerini, Int. J. Mol. Sci. 15 (2014) 8122-8137.

52. I. Landa-Medrano, I. R. de. Larramendi, N. Ortiz-Vitoriano, R. Pinedo, J. I. R. de. Larramendi, T. Rojo, J. Power Sources 249 (2014) 110-117.

53. H. S. Shim, V. R. Shinde, H. J. Kim, Y. E Sung, W. B. Kim, Thin Solids Films 516 (2008) 85738578.

54. M. Teliska, W. E. O’Grady, D. E. Ramaker, J. Phys. Chem. B 109 (2005) 8076-8084.

55. W. Tang, L. Zhang, G. Henkelman, J. Phys. Chem. Lett. 2 (2011) 1328-1331.

56. X. Liu, C. Meng, Y. Han, J. Phys. Chem. C 117 (2013) 1350-1357. 


\section{Figure and Scheme captions}

Fig. 1. High-angle annular dark field scanning TEM (HAADF-STEM) images: morphological imaging and elemental mapping for $\mathrm{Pd}_{21} \mathrm{Cu}_{79}$.

Fig. 2. (A) High energy XRD pattern of pure $\mathrm{Pd}$ and $\mathrm{Pd}_{n} \mathrm{Cu}_{100-\mathrm{n}} / \mathrm{C}$ NPs. (B) Atomic PDFs of model (red and blue lines) and experimental (symbols) data of pure $\mathrm{Pd} / \mathrm{C}$ and $\mathrm{Pd}_{\mathrm{n}} \mathrm{Cu}_{100-\mathrm{n}} / \mathrm{C}$ NPs. Experimental PDFs for pure $\mathrm{Pd}$, $\mathrm{Pd}_{75} \mathrm{Cu}_{25}$ and $\mathrm{Pd}_{21} \mathrm{Cu}_{79}$ NPs are based on a model featuring a single nanophase with fcc-type (Space Group (S.G.): Fm-3m) structure. NP lattice parameters based on the atomic PDFs data are given by each data. The experimental PDF for $\mathrm{Pd}_{50} \mathrm{Cu}_{50}$ NPs can be approximated by a model featuring with one completely chemically disordered of an fcc-type (S.G. Fm-3m) structure, and the other phase is completely chemically ordered of a bcc-type (S.G. Pm-3m) structure. (C) Lattice constant from $\mathrm{HE}-\mathrm{XRD}$ data analysis as a function of $\mathrm{Cu}$ composition in the alloy nanoparticles.

Fig. 3. (A) Comparison of discharge-charge curves for $\mathrm{PdCu} / \mathrm{C}$ catalysts with different binary compositions (a; blue: $\mathrm{Pd}_{21} \mathrm{Cu}_{79}$; b; green: $\mathrm{Pd}_{50} \mathrm{Cu}_{50}$; c; orange: $\mathrm{Pd}_{75} \mathrm{Cu}_{25}$ ). The data for commercial pure $\mathrm{Pd} / \mathrm{C}$ (d; red) and pure carbon catalyst (e; black) are included for comparison. Current density: $0.12 \mathrm{mAcm}^{-2}$ for $1^{\text {st }}$ cycle. Electrolyte in Li- $\mathrm{O}_{2}$ cell: $1.0 \mathrm{M} \mathrm{LiPF}_{6}$ in tetraglyme. (B) Discharge - charge curves for $\mathrm{Pd}_{21} \mathrm{Cu}_{79} / \mathrm{C}$ catalyst under an optimal cell configuration. Current density: (a) $0.12 \mathrm{~mA} \cdot \mathrm{cm}^{-2}$ for 1 st cycle, red curve; (b) $0.06 \mathrm{~mA} \mathrm{~cm} \mathrm{c}^{-2}$ for 2 nd cycle, blue curve. Electrolyte in $\mathrm{Li}-\mathrm{O}_{2}$ cell: $1.0 \mathrm{M} \mathrm{LiPF}_{6}$ in tetraglyme.

Fig. 4. Plots of (A) the discharge (red curve) and charge (black curve) potentials as a function of the bimetallic composition of $\mathrm{PdCu} / \mathrm{C}$ catalyst for the first cycle. The dashed lines serve as a guide to the eye to illustrate the overall trend; (B) Discharge capacity as a function of the bimetallic composition of $\mathrm{PdCu} / \mathrm{C}$ catalyst for the first and second cycle (Current density of 1 st cycle is $0.12 \mathrm{~mA} \cdot \mathrm{cm}^{-2}, 2^{\text {nd }}$ is $0.06 \mathrm{~mA} \cdot \mathrm{cm}^{-2}$.

Fig. 5. (A) Discharge and (B) charge potentials against composition of catalysts at various current density. Current density: (a) $10 \mathrm{~mA} \cdot \mathrm{g}^{-1}$, black; (b) $20 \mathrm{~mA} \cdot \mathrm{g}^{-1}$, red; (c) $40 \mathrm{~mA} \cdot \mathrm{g}^{-1}$, green; (d) $76 \mathrm{~mA} \cdot \mathrm{g}^{-1}$, blue. All the cells have been pre-charged to $200 \mathrm{~mA} \cdot \mathrm{h}^{-\mathrm{g}^{-1}}$. The dashed lines serve as a guide to the eye to illustrate the overall trend.

Fig. 6. (A) Discharge-charge curves of cell with $\mathrm{Pd}_{21} \mathrm{Cu}_{79} / \mathrm{C}$ catalyst (current density: $\left.0.12 \mathrm{~mA} / \mathrm{cm}^{2}\right)(\mathrm{B}) \mathrm{Nyquist}$ plots as a function of state of charge (SOC) or depth of discharge (DOD) (pristine; D1: 0.10 discharge; D2: 0.66 discharge; D3: 0.91 discharge; C1: 100\% Charge; $2^{\text {nd }}$ D1: second cycle 0.28 discharge) for a cell with catalyst $\mathrm{Pd}_{21} \mathrm{Cu}_{79} / \mathrm{C}$.

Fig. 7. (A) Discharge-charge curves for $\mathrm{Pd}_{21} \mathrm{Cu}_{79} / \mathrm{C}$ catalyst (current density: $0.12 \mathrm{~mA} \cdot \mathrm{cm}^{-2}$ ). (B) Nyquist plots as a function of depth of discharge (DOD) (D1-D5: discharge 12\%, 35\%, 57\%, 81\%, 100\% of DOD) (C\&D) Nyquist plots as a function of state of charge (SOC) (C1-C13: charge 19\%, 31\%, 52\%, 69\%, 81\%, 94\%, 106\%, 117\%, 134\%, $150 \%, 179 \%, 206 \%, 210 \%$ of SOC; transition point refers to discharge switch to charge).

Scheme 1. Intermixing of $\mathrm{Pd}$ (grey) and $\mathrm{Cu}($ red) atoms on different crystal plane of (A) bcc and (B) fcc structures of $\mathrm{PdCu}$ nanoalloy. Each $\mathrm{Cu}$ atom has $8 \mathrm{Pd}$ atoms as first neighbor, and so does $\mathrm{Pd}$. Intermixing of $\mathrm{Pd}$ and $\mathrm{Cu}$ atoms on different crystal plane of fcc structures of. $\mathrm{Pd}$ and $\mathrm{Cu}$ atoms occupy the vertices of a cell randomly. Middle inset: illustration of the adsorption of $\mathrm{O}_{2}$ (blue) on $\mathrm{PdCu}$ catalyst (111) plane and the formation and maneuvering of $\mathrm{O}_{2}{ }^{2-}$ ads species in the discharge-charge processes. 